\title{
Effects of the Bacillus thuringiensis Toxin Cry1Ab on Membrane Currents of Isolated Cells of the Ruminal Epithelium
}

\author{
Friederike Stumpff • Angelika Bondzio • \\ Ralf Einspanier · Holger Martens
}

Received: 3 May 2007/Accepted: 18 June 2007/Published online: 5 August 2007

(C) Springer Science+Business Media, LLC 2007

\begin{abstract}
A previous study has shown that Cry1Ab, a lepidopteran-specific toxin derived from Bacillus thuringiensis, does not affect the vitality of cultured cells of the ruminal epithelium of the sheep. While this may be due to lack of specific receptors for toxin action, other mechanisms of resistance should also be considered. In order to directly assess the pore-forming potential of Cry1Ab, we studied the interaction of this toxin with isolated, perfused cells of the ruminal epithelium using the whole-cell and single-channel configurations of the patch-clamp technique. At concentrations found in vivo in the rumen of cows $(<10 \mathrm{ng} / \mathrm{ml})$ and at a temperature of $37^{\circ} \mathrm{C}$, no significant effects of Cry1Ab could be observed. At $100 \mathrm{ng} /$ $\mathrm{ml}$, exposure of ruminal cells to Cry $1 \mathrm{Ab}$ induced a significant rise in outward current in 16 of 34 cells, with a fourfold increase in the conductance for potassium. The cell membrane remained selective for potassium over sodium $(\mathrm{p}[\mathrm{K}] / \mathrm{p}[\mathrm{Na}]=1.8 \pm 0.3)$, with a considerable additional chloride conductance. In outside-out patches, exposure to high Cry1 Ab concentrations induced channellike events that reached levels of over $500 \mathrm{pS}$. We conclude that the unchanged vitality of intact ruminal epithelial cells exposed to Cry1 $\mathrm{Ab}$ in vitro at high concentrations may be related to other factors besides the proposed absence of a specific receptor for the membrane insertion of this toxin.
\end{abstract}

F. Stumpff $(\bowtie) \cdot$ H. Martens

Department of Veterinary Physiology, Free University of Berlin,

Oertzenweg 19b, 14163 Berlin, Germany

e-mail: stumpff@zedat.fu-berlin.de

A. Bondzio · R. Einspanier

Department of Veterinary Biochemistry, Free University of

Berlin, Oertzenweg 19b, 14163 Berlin, Germany
Keywords Bacillus thuringiensis - Patch-clamp · Pore-forming toxin - Rumen - Cry $1 \mathrm{Ab}$

\section{Introduction}

The large group of toxins derived from the $\delta$-endotoxin of the soil-dwelling bacterium Bacillus thuringiensis are tools of increasing importance in the management of insect pests (Griffitts \& Aroian, 2005). Extensive in vivo experience, backed by in vitro studies, suggests that both the naturally occurring protoxin and the genetically engineered derivatives are highly selective and do not target mammalian organisms (Griffitts \& Aroian, 2005; Wieczorek et al., 1999; Wolfersberger, 1992). Mammalian resistance to natively occurring Cry toxins is thought to be due to toxin insolubility, lack of proper proteolytic processing and lack of specific receptors in the mammalian gut (Griffitts et al., 2005). However, despite considerable progress, the search for the exact mechanism by which Cry toxins exert their effects only on some insect populations is ongoing (Griffitts \& Aroian, 2005; Griffitts et al., 2005; Shitomi et al., 2006; Steggles, Wang \& Ellar, 2006; Vachon, Schwartz \& Laprade, 2006; Zhang et al., 2006).

The focus of most studies concerning the interaction of Cry toxins with mammals has been on monogastric species, where Cry toxins are inactivated by the acidic environment of the stomach. In contrast, the gastrointestinal tract of the ruminant is characterized by an extensive forestomach system in which fermentation of ingested material occurs at a neutral $\mathrm{pH}$ value involving enzymes produced by an abundant flora of microorganisms. Thus, production of active toxin appears theoretically possible, and recent studies have demonstrated the presence of one of these toxins, Cry1Ab, as well as some of its fragments in the 
rumen of cows fed genetically modified maize (Chowdhury et al., 2003; Lutz et al., 2005; Wiedemann et al., 2006). Despite this, prima facie evidence suggests that cattle are not adversely affected by ingestion of maize genetically engineered to contain Bt toxin (Folmer et al., 2002), and a recent in vitro study demonstrated that the vitality of cultured ruminal epithelial cells is not affected by active Cry1Ab toxin (A. Bondzio, F. Stumpff, H. Martens, R. Einspanier, Validation of sheep rumen epithelial cells (REC) as a new in vitro model for evaluating the impact of recombinant food compounds, unpublished data).

However, it seems preliminary to conclude from this that $\mathrm{Cry} 1 \mathrm{Ab}$ cannot interact with cells of the ruminal epithelium since the effects may not be sufficient to cause cell death. There can be no doubt that the dramatic consequences of forming a cation-selective pore in the apical membrane of the insect midgut are linked to the extremely unusual absence of a basolateral Na,K-ATPase (Wolfersberger, 1992) in this species. Once the apical membrane is permeabilized by Cry toxins in insect larvae, the transepithelial potential of over $100 \mathrm{mV}$ over the midgut breaks down (Alcantara et al., 2001; Wolfersberger, 1990, 1992), thus eliminating the driving force for uptake of nutrients and maintenance of cell homeostasis. The lack of the need to maintain a transepithelial potential may be one of the reasons that efforts to develop viable cell culture models have been so difficult (Schnepf et al., 1998; Wolfersberger, 1995). A better correlation between in vitro and in vivo effects is found in studies in which the rate of pore formation is assessed directly by measuring the transepithelial conductance of bilayer lipid membranes containing components from the apical membrane of susceptible insects (Peyronnet et al., 2001; Schwartz et al., 1997a).

The ruminal epithelium physiologically expresses cation conductances in the apical membrane (Abdoun et al., 2005; Leonhard-Marek et al., 2005) and relies on a basolateral $\mathrm{Na}^{+}, \mathrm{K}^{+}$-ATPase (Graham \& Simmons, 2005) to maintain transcellular and transepithelial potentials. The cells of this transporting tissue are well equipped to deal with considerable variations in the ionic composition of the ruminal fluid and with the corresponding changes in the influx of ions from the ruminal cavity into the cells. It thus appears possible that the formation of an additional, artificial cationic pore as proposed for Cry toxins in the apical membrane of this tissue does not lead to cell lysis.

In light of substantial evidence for the ability of Cry toxins to form pores in artificial bilayers in the absence of specific receptors (Gazit et al., 1994; Grochulski et al., 1995; Lee et al., 2003; Peyronnet et al., 2001; Rausell et al., 2004; Schwartz et al., 1993; Vie et al., 2001; Walters et al., 1993), we investigated the interactions of Cry1 Ab with the cell membrane of ruminal epithelial cells directly using the patch-clamp technique.

\section{Materials and Methods}

\section{Cells}

The rumen was removed immediately after the slaughter of sheep, and cells were isolated according to established methods (Schweigel, Lang \& Martens, 1999) by fractional trypsinization. After about 1 week in culture, cells were reseeded onto glass coverslips and cultured for another 2-4 days. The glass coverslip with the cells was then introduced into a perfusion chamber on the stage of an inverted microscope. Unless indicated, cells were gently cleansed with trypsin (0.02\%; Biochrome, Berlin, Germany) for about 1 min under microscopic control to enhance seal formation.

\section{Electrophysiology}

All patch-clamp experiments were performed essentially as in previous studies (Abdoun, Stumpff \& Martens, 2006; Leonhard-Marek et al., 2005; Stumpff et al., 2005). Pipettes were pulled with a DMZ-Universal-Puller (Zeitz-Instruments, Munich, Germany) from borosilicate glass capillaries (Harvard Apparatus, Holliston, MA). Currents between the patch pipette and an electrode placed in the perfusion chamber were recorded using an EPC 9 patch-clamp amplifier (HEKA Elektronic, Lambrecht, Germany). Pulse generation, data collection and data analysis were performed using TIDA for Windows software (HEKA Elektronic); and data were filtered with a $2.9-\mathrm{kHz}$ Bessel filter. Records were corrected for capacitance via TIDA software. Positive ions flowing into the pipette correspond to a negative current and are depicted in figures as going downward.

Two types of pulse protocols were used. Either current responses were recorded at $100 \mathrm{~Hz}$ using a protocol that generated steps of $200 \mathrm{~ms}$ duration in between to voltages between -120 and $100 \mathrm{mV}$ in $20-\mathrm{m} V$ steps, returning to a holding potential of $-40 \mathrm{mV}$ for $200 \mathrm{~ms}$ (pulse protocol I, see Fig. 1). This protocol was repeated continuously to allow monitoring of current responses of the cells to changes in external solution. In addition, conventional voltage pulse protocols were used that recorded data at a much higher sampling rate of $5 \mathrm{kHz}$ (pulse protocol II, see Fig. 5a). As before, holding potential was $-40 \mathrm{mV}$, and voltages ranged from -120 to $100 \mathrm{~m} V$; but the step size was $10 \mathrm{~m} V$. For single-channel experiments, data were sampled at $10 \mathrm{kHz}$ and filtered with a $125-\mathrm{kHz}$ or $50-\mathrm{kHz}$ low-pass Bessel filter (TIDA, Heka Elektronic, Lambrecht, Germany) after recording.

In all experiments, cells were allowed to equilibrate for at least 3 min after the whole-cell configuration had been achieved. During this time, voltages were clamped in alteration with pulse protocols I and II and current was 


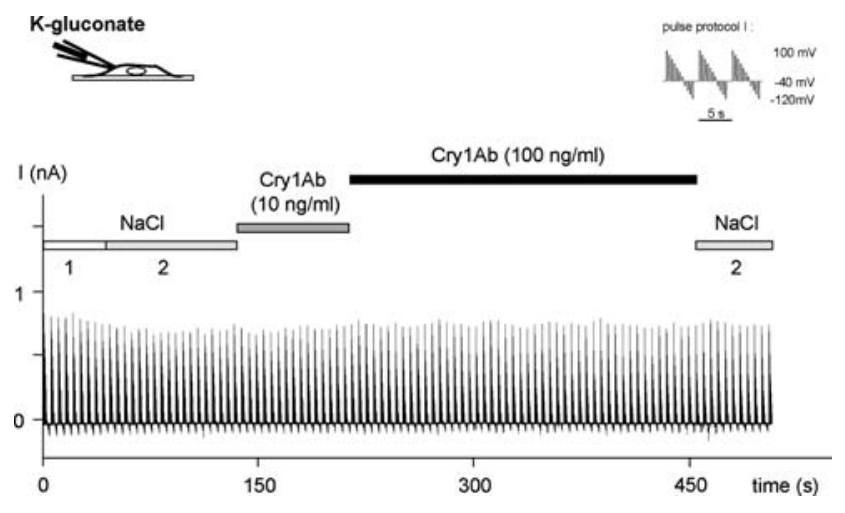

Fig. 1 Cells were filled with K-gluconate pipette solution and superfused with $\mathrm{NaCl}$ solution for $3 \mathrm{~min}$. Subsequently, bath perfusion was switched to a control solution $(\mathrm{NaCl} 2$, see "Materials and Methods"). Addition of Cry1 Ab in concentrations of 10 and 100 $\mathrm{ng} / \mathrm{ml}$ followed. The trace shows data from a cell that did not respond to application of Cry $1 \mathrm{Ab}$

monitored. Cells that did not reach stable outward or inward current levels during this equilibration period were discarded. All other cells were included in the study and monitored continuously with pulse protocol I for an additional $150 \mathrm{~s}$ before the first change in bath solution. If the current-voltage relationship was linear with no signs of channel activation/inactivation and a reversal potential of 0 $\mathrm{m} V$ was measured, the seal was judged to be ruptured and the measurement discontinued.

\section{Solutions and Chemicals}

Pipette solution for both whole-cell and outside-out experiments, designated as "K-gluconate," contained (mmol . $\left.1^{-1}\right) 1 \mathrm{KH}_{2} \mathrm{PO}_{4}, 10$ 4-(2-hydroxyethyl)-1-piperazineethanesulfonic acid (HEPES), $0.8 \mathrm{CaCl}_{2}, 0.9 \mathrm{MgSO}_{4}, 5$ ethyleneglycoltetraacetic acid (EGTA), $123 \mathrm{~K}$-gluconate and $10 \mathrm{NaCl}$. In a few cells, an alternate solution, designated as "divalent free K-gluconate solution," was used in which $\mathrm{CaCl}_{2}$ and $\mathrm{MgCl}_{2}$ were substituted by $2.5 \mathrm{mmol} \cdot \mathrm{1}^{-1}$ choline chloride. Extracellular $\mathrm{NaCl}$ solution (referred to as " $\mathrm{NaCl} 1$ " in the following) contained (mmol $\left.\cdot 1^{-1}\right) 130$ $\mathrm{NaCl}, 1 \mathrm{NaH}_{2} \mathrm{PO}_{4}, 5 \mathrm{KCl}, 10 \mathrm{HEPES}, 1.7 \mathrm{CaCl}_{2}$ and 0.9 $\mathrm{MgCl}_{2}$. Using this basic recipe, $\mathrm{NaCl}$ was substituted by either $\mathrm{KCl}$, Na-gluconate or $\mathrm{K}$-gluconate in the solutions designated by these ions. Osmolarity of all solutions was adjusted to a value of $290 \mathrm{~mm}$ by appropriate amounts of the dominant salt.

Cry $1 \mathrm{Ab}$ toxin was kindly provided by Dr. J. Jehle, Laboratory for Biotechnological Crop Protection, Department of Phytopathology, Agricultural Service Center Palatinate (DLR Rheinpfalz), Breitenweg 71, 67435 Neustadt an der Weinstrasse, Germany, within the project $01 \mathrm{~K} 0-31 \mathrm{P} 2614$. The protoxin was prepared from
Escherichia coli $\mathrm{HB} 101 / \mathrm{pMP}$ and activated by trypsinization as described by Nguyen Thu et al. (2004). Purity was confirmed by sodium dodecyl sulfate-polyacrylamide gel electrophoresis and toxicity by a bioassay on susceptible Ostrinia nubilalis larvae. For the present study, a frozen 2 $\mathrm{mg} / \mathrm{ml}$ sample of this preparation of toxin was diluted tenfold with pure water to a concentration of $0.2 \mathrm{mg} / \mathrm{ml}$, mixed by gentle vortexing for about $2 \mathrm{~min}$ and frozen in aliquots of $10 \mu \mathrm{l}$ each. These aliquots were thawed and added to appropriate amounts of test Ringer's ( $\mathrm{NaCl} 1)$ solution yielding end concentrations of 10 or $100 \mathrm{ng} / \mathrm{ml}$ as indicated. The solutions were mixed by shaking, followed by recirculation in the perfusion system (see below) for a maximum of $2 \mathrm{~h}$ until use. Solutions remained at room temperature throughout until immediately before contact with the cells. Control Ringer's solution (referred to as " $\mathrm{NaCl} 2$ " in the following) was prepared by addition of $10 \mu \mathrm{l}$ of pure water per $20 \mathrm{ml}$ of $\mathrm{NaCl} 1$ solution.

\section{Perfusion}

All perfusion solutions were warmed to $37^{\circ} \mathrm{C}$ immediately before infusion into the $200 \mathrm{ml}$ perfusion chamber via a perfusion cannula (PH01; Multichannel Systems, Reutlingen, Germany) connected to a temperature controller (TC01/2, Multichannel Systems). To ensure identical flow rates $(4 \mathrm{ml} / \mathrm{min})$, the solutions designated as $\mathrm{NaCl} 1, \mathrm{NaCl}$ 2, Cry1Ab $10 \mathrm{ng} / \mathrm{ml}$ and Cry1Ab $100 \mathrm{ng} / \mathrm{ml}$ were applied via parallel lanes of the same roller pump (MS/CA4/840; Ismatec, Glattbrugg-Zürich, Switzerland) via high-precision tygon tubing (Ismatec). Four additional solutions could be applied via the four parallel lanes of a separate but identical pump. All eight lanes ended in a millimanifold (ALA Scientific Instruments, Westbury, NY) attached to the heating cannula (PH01) and leading into the perfusion chamber. Solution of lanes not in immediate use for cell perfusion was recirculated into the storage containers (50ml syringes; Heiland, Hamburg, Germany) via eight separate three-lane valves, ensuring constant mixing and constant pressure in all parts of the system at all times and preventing backflow of the solution being tested into other parts of the system via the manifold.

\section{Videoimaging}

Throughout the measurements, the shape of the cells as seen through an inverted microscope (Axiovert 25; Carl Zeiss, Oberkochen, Germany) attached to a charge-coupled device camera (AVC-D5CE with adaptor CMA-D5CE; Sony, Tokyo, Japan) was monitored via commercial video equipment. 
Table 1 Summary of all data: effect of Cry1Ab on inward current $(I[-120 \mathrm{~m} V])$, outward current $(I[100 \mathrm{~m} V])$ and reversal potential of ruminal epithelial cells

\begin{tabular}{llllllcc}
\hline Solution & $I(-120 \mathrm{mV})(\%)$ & $p(v s . \mathrm{NaCl} \mathrm{1)}$ & $I(+100 \mathrm{mV})(\%)$ & $p(v s . \mathrm{NaCl} \mathrm{1)}$ & $\begin{array}{l}\text { Reversal } \\
\text { potential }(\mathrm{m} V)\end{array}$ & $p(v s . \mathrm{NaCl} \mathrm{1)}$ & $\begin{array}{l}\text { Number } \\
\text { of cells }\end{array}$ \\
\hline $\mathrm{NaCl} \mathrm{1}$ & 100 & & 100 & & $-28 \pm 2$ & 34 \\
$\mathrm{NaCl} 2$ & $104 \pm 5$ & 0.5 & $102 \pm 5$ & 0.7 & $-26 \pm 2$ & 0.3 \\
$\mathrm{Cry} 1 \mathrm{Ab}(10 \mathrm{ng} / \mathrm{ml})$ & $231 \pm 99$ & 0.2 & $157 \pm 34$ & 0.1 & $-25 \pm 3$ & 0.4 & 20 \\
$\mathrm{Cry} 1 \mathrm{Ab}(100 \mathrm{ng} / \mathrm{ml})$ & $727 \pm 355$ & 0.08 & $228 \pm 40$ & 0.003 & $-25 \pm 2$ & 0.1 & 19 \\
$\mathrm{NaCl} \mathrm{2}$ & $215 \pm 34$ & 0.002 & $212 \pm 47$ & 0.03 & $-27 \pm 2$ & 0.8 & 24 \\
\hline
\end{tabular}

Mean \pm SEM; $p<0.05$ was considered significant

Analysis

To compare whole-cell data from different cells with each other, currents in $\mathrm{NaCl}$ solution before the first change in solution were assigned the value of $100 \%$ and designated as "outward" if positive (at $100 \mathrm{mV}$ pipette potential) or "inward" if negative (at $-120 \mathrm{mV}$ ). All other currents were seen in relation to these values. Reversal potentials were estimated by linear regression between the current values just above and just below the zero level for each cell and corrected for liquid junction potential. In single-channel experiments, conductance levels were calculated using the equation $g_{\mathrm{k}}=I /\left(E-E_{\mathrm{k}}\right)$, where $I$ is the current, $E$ the pipette potential and $E_{\mathrm{k}}$ is the Nernst potential for potassium.

The relative permeability ratio of chloride to potassium was calculated from the reversal potential of K-gluconatefilled cells in $\mathrm{KCl}$ solution by disregarding the low contribution of sodium $\left([\mathrm{Na}]_{o}=10 \mathrm{~mm},[\mathrm{Na}]_{i}=10 \mathrm{~mm}\right)$ to total conductance and using the Nernst equation for two ions (Hille, 2001, Eq. 14.10):

$$
\begin{aligned}
\mathrm{E}= & R \cdot T / F \cdot \ln \left\{\mathrm{p}(\mathrm{K}) \cdot[\mathrm{K}]_{\mathrm{o}}+\mathrm{p}(\mathrm{Cl}) \cdot[\mathrm{Cl}]_{\mathrm{i}}\right\} /\left\{\mathrm{p}(\mathrm{K}) \cdot[\mathrm{K}]_{\mathrm{i}}\right. \\
& \left.+\mathrm{p}(\mathrm{Cl}) \cdot[\mathrm{Cl}]_{\mathrm{o}}\right\}
\end{aligned}
$$

from which the following equation was derived:

$$
\begin{aligned}
\mathrm{p}(\mathrm{K}) / \mathrm{p}(\mathrm{Cl})=\{ & {\left.[\mathrm{Cl}]_{\mathrm{i}}-[\mathrm{Cl}]_{\mathrm{o}} \cdot \exp (E \cdot F / R \cdot T)\right\} / } \\
& \left\{[\mathrm{K}]_{\mathrm{i}} \cdot \exp (E \cdot F / R \cdot T)-[\mathrm{K}]_{\mathrm{o}}\right\}
\end{aligned}
$$

In this equation, $E$ is the reversal potential, $R$ is the gas constant, $F$ is the Faraday constant, $T$ is the absolute temperature, $[\mathrm{K}]_{i}$ and $[\mathrm{Cl}]_{i}$ are the internal (pipette) concentrations for potassium and chloride, $[\mathrm{Cl}]_{o}$ and $[\mathrm{K}]_{o}$ are the respective external (bath) concentrations and $\mathrm{p}(\mathrm{K})$ and $\mathrm{p}(\mathrm{Cl})$ are the respective permeabilities of the ruminal epithelial cell to these ions.

Significance testing was performed using the paired Student's $t$-test and standard software (Sigmaplot 8.0, Systat Software Inc., San Jose, California, USA). " $n$ " refers to the number of cells used, and " $N$ " designates the number of sheep.

\section{Results}

Effects of Cry1Ab on Sheep Rumen Epithelial Cells

After seal formation, cells were allowed to equilibrate for at least $3 \mathrm{~min}$ in $\mathrm{NaCl}$ solution to ensure complete internal perfusion with the K-gluconate pipette solution before the start of the experiment. After this time, 34 cells reached stable current values with mean inward current at $-120 \mathrm{mV}$ reaching $-14 \pm 3 \mathrm{pA} / \mathrm{pF}$, while mean outward current at $100 \mathrm{~m} V$ was $36 \pm \mathrm{pA} / \mathrm{pF}$, with reversal potential at $-28 \pm 2$ $\mathrm{m} V$. Cells showed outward rectification, with inward current at $-100 \mathrm{mV}$ being only $33 \pm 4 \%$ of the outward current at $+100 \mathrm{mV}$.

In a first group of 14 cells, Cry $1 \mathrm{Ab}$ was added immediately in a concentration of $100 \mathrm{ng} / \mathrm{ml}$ following the equilibration period and the $150-\mathrm{s} \mathrm{NaCl}$ prerun (group I). To test for unspecific effects, a second experimental protocol was used in 20 of the 34 cells (group II). In these cells, referred to as "treated" below, the solution was first switched to an $\mathrm{NaCl}$ solution that contained an aliquot of pure water with no Cryl $\mathrm{Ab}$ toxin added $(\mathrm{NaCl}$ $2)$. Cry $1 \mathrm{Ab}$ was added subsequently, first in a concentration of $10 \mathrm{ng} / \mathrm{ml}$ and then elevated to the final concentration of $100 \mathrm{ng} / \mathrm{ml}$, followed by a washout phase with $\mathrm{NaCl} 2$ solution.

\section{Switch to $\mathrm{NaCl} 2$ solution}

Switch of the perfusion solution to the test solution with an aliquot of water did not change either outward current, inward current or reversal potential (see Table 1).

\section{Application of CrylAb in a concentration of $10 \mathrm{ng} / \mathrm{ml}$}

After application of Cry $1 \mathrm{Ab}$ in $\mathrm{NaCl}$ solution in a concentration of $10 \mathrm{ng} / \mathrm{ml}$, cells showed no significant changes in outward current, inward current or reversal potential (Table 1). 
Table 2 Nonresponders: Cry1 Ab had no effect on inward current $(I[-120 \mathrm{mV}])$, outward current $(I[100 \mathrm{~m} V])$ and reversal potential of 18 of 34 ruminal epithelial cells

\begin{tabular}{llllllcc}
\hline Solution & $I(-120 \mathrm{mV})(\%)$ & $p(v s . \mathrm{NaCl} \mathrm{1)}$ & $I(+100 \mathrm{mV})(\%)$ & $p(v s . \mathrm{NaCl} \mathrm{1)}$ & $\begin{array}{l}\text { Reversal } \\
\text { potential }(\mathrm{m} V)\end{array}$ & $p(v s . \mathrm{NaCl} \mathrm{1)}$ & $\begin{array}{l}\text { Number } \\
\text { of cells }\end{array}$ \\
\hline $\mathrm{NaCl} \mathrm{1}$ & 100 & & 100 & & $-28 \pm 2$ & 18 \\
$\mathrm{NaCl} 2$ & $105 \pm 7$ & 0.5 & $97 \pm 6$ & 0.6 & $-26 \pm 3$ & 0.5 \\
$\mathrm{Cry} 1 \mathrm{Ab}(10 \mathrm{ng} / \mathrm{ml})$ & $103 \pm 10$ & 0.7 & $90 \pm 8$ & 0.2 & $-25 \pm 3$ & 0.04 \\
$\mathrm{Cry} 1 \mathrm{Ab}(100 \mathrm{ng} / \mathrm{ml})$ & $105 \pm 5$ & 0.4 & $86 \pm 5$ & 0.02 & $-25 \pm 2$ & 0.04 \\
$\mathrm{NaCl} \mathrm{2}$ & $103 \pm 5$ & 0.6 & $85 \pm 4$ & 0.004 & $-25 \pm 2$ & 0.1 & 18 \\
\hline
\end{tabular}

Mean \pm SEM; $p<0.05$ was considered significant

Table 3 Responders: Cry1 Ab (100 ng/ml) visibly increased inward current $(I[-120 \mathrm{~m} V])$, outward current $(I[100 \mathrm{~m} V])$ and reversal potential of 16 of 34 ruminal epithelial cells

\begin{tabular}{llllllcc}
\hline Solution & $I(-120 \mathrm{mV})(\%)$ & $p(v s . \mathrm{NaCl} \mathrm{1)}$ & $I(+100 \mathrm{mV})(\%)$ & $p(v s . \mathrm{NaCl} \mathrm{1)}$ & $\begin{array}{l}\text { Reversal } \\
\text { potential (mV) }\end{array}$ & $p(v s . \mathrm{NaCl} \mathrm{1)}$ & $\begin{array}{l}\mathrm{Number} \\
\text { of cells }\end{array}$ \\
\hline $\mathrm{NaCl} \mathrm{1}$ & 100 & & 100 & & $-27 \pm 4$ & 16 \\
$\mathrm{NaCl} 2$ & $103 \pm 8$ & 0.7 & $103 \pm 6$ & 0.6 & $-25 \pm 3$ & 0.5 \\
$\mathrm{Cry} 1 \mathrm{Ab}(10 \mathrm{ng} / \mathrm{ml})$ & $325 \pm 168$ & 0.2 & $206 \pm 55$ & 0.08 & $-25 \pm 4$ & 0.9 & 10 \\
$\mathrm{Cry} 1 \mathrm{Ab}(100 \mathrm{ng} / \mathrm{ml})$ & $1,427 \pm 726$ & 0.08 & $387 \pm 67$ & 0.0006 & $-26 \pm 3$ & 0.7 & 16 \\
$\mathrm{NaCl} \mathrm{2}$ & $348 \pm 49$ & 0.0005 & $361 \pm 83$ & 0.01 & $-30 \pm 3$ & 0.3 & 11 \\
\hline
\end{tabular}

Mean \pm SEM; $p<0.05$ was considered significant

\section{Application of CrylAb in a concentration of $100 \mathrm{ng} / \mathrm{ml}$}

After application of Cry1 Ab in a concentration of $100 \mathrm{ng} /$ $\mathrm{ml}$, mean outward current at $100 \mathrm{~m} V$ rose significantly (see Table 1). Changes in inward current (at $-120 \mathrm{mV}$ ) did not reach significance level. Reversal potential remained negative. Cells showed great variability, with roughly half of the cells showing no response to Cry1 Ab (Table 2, Fig. 1; "nonresponders"), while in the other half of the cells, a significant visible increase in outward current could be observed, the beginning of which correlated timewise with application of Cry1Ab (Table 3, Fig. 2; "responders").

\section{Nonresponders}

Of the total of 34 cells, 18 showed no visible response to application of Cry $1 \mathrm{Ab}$ in a concentration of $100 \mathrm{ng} / \mathrm{ml}$ (Fig. 1). A slight, continuous decline in outward current levels can probably be attributed to rundown effects due to the washout of cytosolic substrates over the time course of the experiment (Table 2).

\section{Responders}

Conversely, 16 of 34 cells showed pronounced and clearly visible rises in outward current (see Figs. 2-4, Table 3).

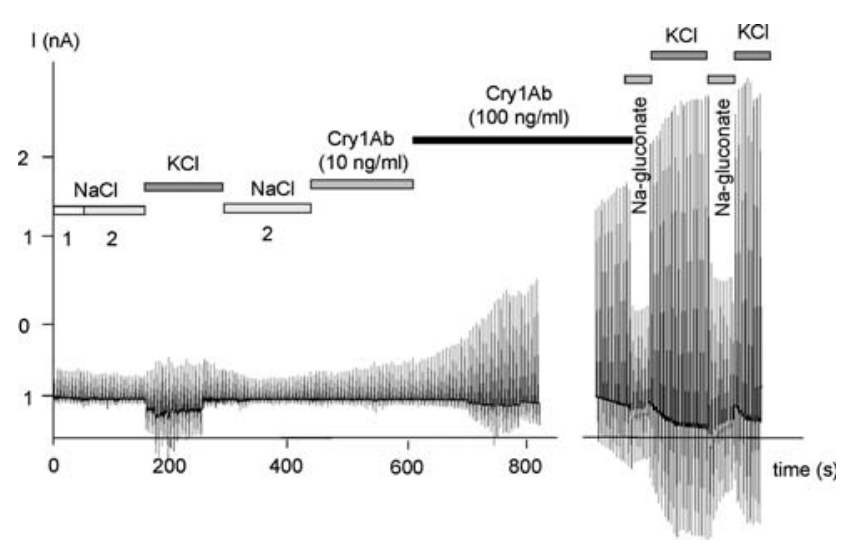

Fig. 2 In this cell, brief exposure to $\mathrm{KCl}$ solution preceded exposure to $\mathrm{Cry} 1 \mathrm{Ab}$, demonstrating the increase in inward current and slight increase in outward current previously described (Abdoun et al., 2005). Addition of Cry1 Ab in a concentration of $10 \mathrm{ng} / \mathrm{ml}$ did not have a significant effect. At a larger concentration of $100 \mathrm{ng} / \mathrm{ml}$, $\mathrm{Cry} 1 \mathrm{Ab}$ resulted in the induction of a strong rise in outward and inward currents. The time gap in the trace reflects the fact that the recording was stopped to switch to a less sensitive gain range and to check membrane potential (which had changed from -18 to $-31 \mathrm{mV}$ in this cell) and cell capacitance (from 69 to $72 \mathrm{pA} / \mathrm{pF}$ ). Note the dramatic impact of removal of chloride on outward current and the potassium-induced inward currents

The extent of the rise in outward current did not depend on whether the cell had been pretreated (group II: $377 \pm 93 \%$, $n=11$ ) or not (group I: $407 \pm 68 \%, n=5)(p=0.8)$, but the rate of responders appeared to be higher in group II (11 of 


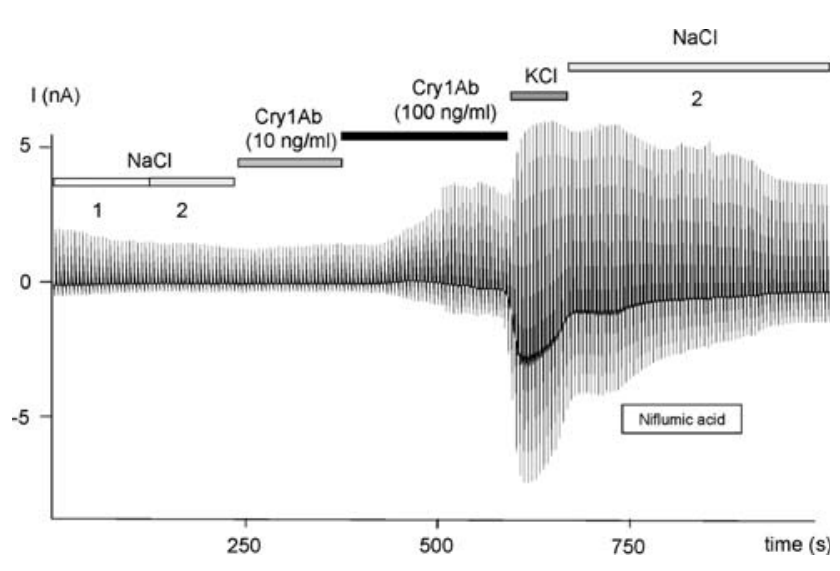

Fig. 3 In this cell, the chloride channel blocker niflumic acid (100 $\mu \mathrm{mol} / \mathrm{l})$ was added to the $\mathrm{NaCl}$ solution in the washout phase after application of Cry1Ab. Effects on outward current were small; the corresponding impact on inward current suggests that washout was more important than any effects of the blocker

$19 v s .5$ of 15). In this group, the total time of exposure to Cry1 Ab was longer.

Relative inward current rise in the group of cells identified as responders showed considerable scatter, with three cells showing extremely high relative inward current rises (in \%) due to low initial values. When expressed as percent of initial inward current, this rise did not pass testing for significance. In absolute terms, inward current rose to a mean value of $-112 \pm 50 \mathrm{pA} / \mathrm{pF}$ (up from $-14 \pm 6 \mathrm{pA} / \mathrm{pF}$, $p=0.04, n=16$ ).

Responding and nonresponding cells were scattered across the entire experimental period. In the first third of the experimental period 3 of 11 cells were labeled as "responders," in the second third 6 of 11 cells and in the third 7 of 12 cells. Four cells were not treated with trypsin prior to seal formation, two of which responded.

\section{Cell capacitance}

Mean capacitance of responding cells was not significantly different from that of nonresponders $(58 \pm 7$ and $45 \pm 6 \mathrm{pF}$, $p=0.2$ ). Cell capacitance did not change significantly in either the collective as a whole or in the two groups after addition of Cry1 Ab $(p>0.2)$.

\section{Washout of Cry toxin with $\mathrm{NaCl}$ solution and reexposure to CrylAb}

In 11 responding cells, current was monitored after the Cry1 Ab-induced rise. In three cells, clear signs of washout could be observed. Two of these cells were reexposed to Cry1Ab (100 ng/ml), and the effects of Cry1 Ab could be repeated (Fig. 4).

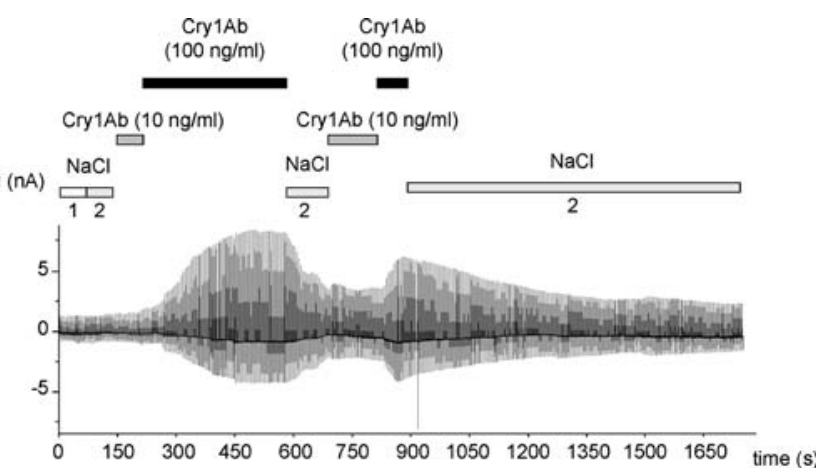

Fig. 4 Trace of a cell showing washout and a second response after reapplication of Cry $1 \mathrm{Ab}$

\section{Exposure to $\mathrm{KCl}$ Solution}

To test for conductance to potassium, cells that had responded to the addition of Cry1 Ab $(100 \mathrm{ng} / \mathrm{ml})$ were subsequently superfused with $\mathrm{KCl}$ solution (135 mM) (Figs. 2, 3). Inward current rose to $1,215 \pm 231 \%(-120$ $\mathrm{m} V, n=9$ ), up from the values observed in $\mathrm{NaCl}$ solution at the beginning of the experiment $(100 \%, p=0.0001)$ and in $\mathrm{NaCl}$ solution after exposure to Cry1 Ab $(487 \pm 126 \%, p=$ 0.001). In three nonresponding cells or control cells $(n=$ 20) not treated with Cry $1 \mathrm{Ab}$ toxin, the same maneuver induced much smaller rises of inward current $(382 \pm 105$ $[n=3]$ and $344 \pm 52 \%[n=20], p=0.000001$ vs. Cry1Abtreated). Thus, the permeability of the cells for potassium influx rises by roughly a factor of four after exposure to Cry1Ab (compare Fig. 2).

Reversal potential of Cry1 Ab-treated cells in $\mathrm{KCl}$ solution was $-18 \pm 4 \mathrm{mV}(n=9)$, significantly higher than the value in $\mathrm{NaCl}$ solution $(p=0.003)$. Using the GoldmanHodgkin-Katz equation $\left(E_{\mathrm{rev}, \mathrm{K}}-E_{\mathrm{rev}, \mathrm{Na}}=R \cdot T /\left\{F \cdot \ln \left(\mathrm{P}_{\mathrm{K}}\right.\right.\right.$ $[\mathrm{K}]_{\mathrm{o}} / \mathrm{P}_{\mathrm{Na}}[\mathrm{Na}]_{\mathrm{o}}$ ) $\}$ (Hille, 2001, Eq. 14.17), it is possible to calculate a value for the relative permeability of $\mathrm{Na}$ to $\mathrm{K}$ from the reversal potentials in $\mathrm{NaCl}$ and $\mathrm{KCl}$ solution of $\mathrm{p}(\mathrm{K}) / \mathrm{p}(\mathrm{Na})=1.8 \pm 0.3$.

It should be noted that the reversal potential in $\mathrm{KCl}$ solution was significantly lower than zero $(p=0.01)$. This suggests that chloride also contributed to the reversal potential of cells exposed to Cry1Ab toxin. As outlined above in "Materials and Methods," it is possible to estimate the relative permeability of the membrane for chloride and potassium from this reversal potential, yielding a value of $\mathrm{p}(\mathrm{Cl}) / \mathrm{p}(\mathrm{K})=0.7 \pm 0.3$.

\section{Removal of Chloride}

To isolate potassium from chloride currents, cells with a $\mathrm{Cry} 1 \mathrm{Ab}$-induced rise in membrane current were exposed to Na-gluconate bath solution. In this subgroup of cells, 
Fig. 5 Single-channel recordings. a Conventional pulse protocol of cell before patch excision. b Recording of patch in $\mathrm{NaCl}$ solution containing $10 \mathrm{ng} / \mathrm{ml}$ of Cry $1 \mathrm{Ab}$ $($ at $+60 \mathrm{mV}$ ). c Same patch in the presence of $100 \mathrm{ng} / \mathrm{ml}$ Cry1Ab. d Channel-like events with very high conductances could be observed both in $\mathrm{NaCl}$ and in K-gluconate solution
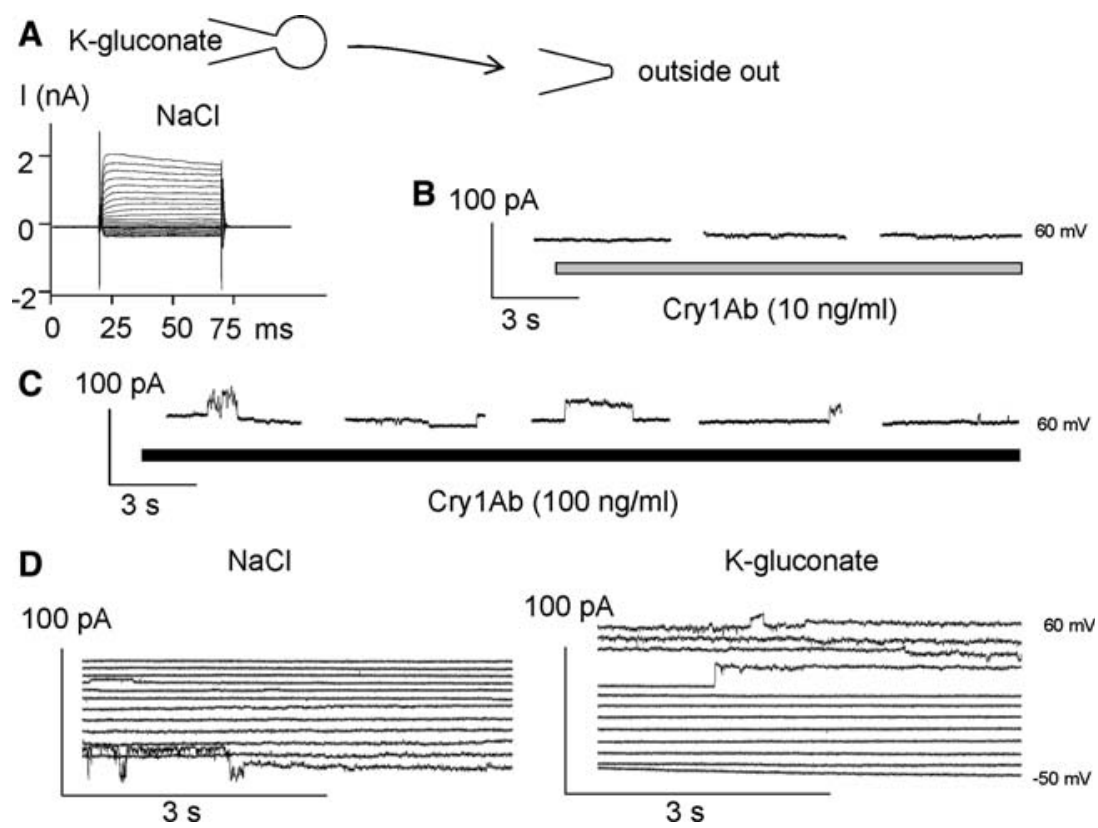

treatment with Cry $1 \mathrm{Ab}(100 \mathrm{ng} / \mathrm{ml})$ resulted in a mean rise of outward current to $615 \pm 152 \%$ of the current observed at the beginning of the experiment in $\mathrm{NaCl}$ solution. After replacement of chloride by gluconate, the current dropped to $243 \pm 88 \%(p=0.01, n=5)$, with subsequent recovery in $\mathrm{NaCl}(639 \pm 189 \%)$ (Fig. 2). The outward current in Nagluconate solution must represent an efflux of potassium; conversely, the difference between the outward current in $\mathrm{NaCl}$ solution and in Na-gluconate solution should represent chloride influx (372 $\pm 88 \%)$.

Removal of chloride did not significantly change inward current $(128 \pm 27 \%, p=0.4)$. Reversal potential in Nagluconate solution was $2 \pm 4 \mathrm{mV}(p=0.002 v s$. the value in $\mathrm{NaCl}$ solution).

\section{Buffering of Intracellular Divalent Cations}

It has been suggested that Cry toxin action is related to a calcium- or magnesium-dependent signaling pathway with subsequent activation of ionic channels (Monette et al., 1994; Zhang et al., 2006). In this case, a depletion of cytosolic $\mathrm{Ca}^{2+}$ and $\mathrm{Mg}^{2+}$ might impede Cry toxin action. For this reason, four cells were filled with a pipette solution that contained no calcium and no magnesium, and the usual $3 \mathrm{~min}$ were allowed for equilibration and washout of divalent cations from stores. Cells responded to application of Cry $1 \mathrm{Ab}(100 \mathrm{ng} / \mathrm{ml})$ with a depolarization from $-25 \pm 3$ to $-14 \pm 2 \mathrm{mV}(n=4, p=0.04)$, with a slight recovery to $-16 \pm 2 \mathrm{mV}(n=4, p=0.05)$. Clear changes in outward and inward current were visible in two of these cells, reaching levels of $304 \%$ and $1,319 \%$, respectively, with rises in inward current of $727 \%$ and $1,850 \%$. Reversal potential remained clearly negative ( -17 and $-11 \mathrm{mV}$ ), suggesting a conductance for chloride. Cells showed some recovery after washout of Cry1 $\mathrm{Ab}(-19$ and $-13 \mathrm{mV}$, respectively).

\section{Single-Channel Measurements}

After seal formation and formation of the whole-cell configuration with K-gluconate solution in the pipette and $\mathrm{NaCl}$ in the bath (Fig.5a), the patch pipette was pulled back to yield a patch in the outside-out configuration. This patch was continuously exposed to a protocol in which voltage was alternated between 0 and $+60 \mathrm{~m} V$ pipette potential for $6 \mathrm{~s}$ each and monitored for channel activity for $120 \mathrm{~s}$ in $\mathrm{NaCl}$ solution. If seals were found to be stable and to not display endogenous current activity, solution was switched to the Cry $1 \mathrm{Ab}$-containing $\mathrm{NaCl}$ solutions (first $10 \mathrm{ng} / \mathrm{ml}$, then $100 \mathrm{ng} / \mathrm{ml}$ ) (Fig. 5b, c).

Of six patches exposed to Cry1 Ab solution, four showed outwardly directed channel-like events that grew in magnitude with the duration of Cry $1 \mathrm{Ab}$ exposure. Conductance was variable and tended to rise with the duration of toxin application. Since conductance could represent either potassium flowing out of or chloride flowing into the patch, the bath solution was switched to K-gluconate solution in two cases. Channel-like events persisted, reaching levels of over 500 pS (Fig. 5d).

\section{Videoimaging}

Throughout the measurements, cells were monitored optically for changes in shape or size. Neither the patch- 
clamped cells nor the surrounding cells showed obvious signs of blebbing or lysis.

\section{Discussion}

Recent studies have presented evidence for the presence of very low concentrations $(<4 \mathrm{ng} / \mathrm{ml})$ of Cry1 Ab toxin in the rumen of cows fed genetically modified maize (Chowdhury et al., 2003; Lutz et al., 2005). In this study, perfused, isolated sheep ruminal epithelial cells were exposed to Cry $1 \mathrm{Ab}$ toxin at a temperature of $37^{\circ} \mathrm{C}$. At $10 \mathrm{ng} / \mathrm{ml}$, we were not able to observe significant results of application of $\mathrm{Cry} 1 \mathrm{Ab}$ toxin either in the whole-cell or the single-channel configuration, which can be regarded as supporting the notion that $\mathrm{Bt}$ maize is not toxic to animals in vivo.

In a second series of experiments, we attempted to provoke a response by elevating the concentration to 100 $\mathrm{ng} / \mathrm{ml}$, a concentration that is 20 times higher than that seen in vivo but lower than the concentrations used in most studies of pore formation in lipid bilayers. A recent study did not show effects of Cry1Ab toxin on the vitality of cultured ruminal epithelial cells at this concentration (A. Bondzio, F. Stumpff, H. Martens, R. Einspanier, Validation of sheep rumen epithelial cells (REC) as a new in vitro model for evaluating the impact of recombinant food compounds, unpublished data). Using the patch-clamp technique, however, we observed a significant increase in whole-cell conductance in half of the cells exposed to 100 $\mathrm{ng} / \mathrm{ml}$ of Cry1Ab toxin and an induction of channel-like activity in previously silent membrane patches. In some cells, washout could be observed after removal of Cry1Ab, and two cells survived long enough to demonstrate reproducibility of the Cry1 Ab effect.

For a number of reasons, we do not think that the current responses reported in this study are the result of artifacts such as cell swelling or seal rupture. As in other studies performed in this laboratory (Abdoun et al., 2005; Leonhard-Marek et al., 2005), current was monitored for several minutes before the beginning of the actual experiment. Only cells were included that showed stable properties after this period. Cry1Ab was added to the same solution used in this stabilization period, and a difference in osmolarity between the Cry1Ab-containing and the control solution can be excluded. Likewise, the effects cannot be explained by rupture of the seal since rectification of membrane currents could be observed and membrane potential remained negative throughout. Furthermore, it was possible to observe specific responses to changes in the ionic composition of the external solution after application of Cry1Ab.

The variability of the channel-like events observed in this study in the single-channel configuration resembles the
Cry toxin-induced channels observed by others in receptorfree lipid bilayers (Masson et al., 2002; Peyronnet et al., 2001; Schwartz et al., 1993, 1997a; Slatin, Abrams \& English, 1990) as did the high conductance of several hundred pico Siemens ( $\mathrm{pS}$ ). In cells of sheep ruminal epithelium, we have recently observed endogenous potassium channels with a conductance of $135 \mathrm{pS}$, and there are even larger chloride channels in these cells (Abdoun et al., 2005); however, neither reaches the remarkable levels observed in this study. While we cannot exclude activation of endogenous channels by Cry1 Ab, the most plausible explanation for the very large conductances observed is formation of pores comparable to those reported from experiments with artificial lipid bilayer systems (Masson et al., 2002; Slatin et al., 1990).

In cells treated with Cry1 $\mathrm{Ab}$, the relative permeability to potassium $(\mathrm{p}[\mathrm{K}] / \mathrm{p}[\mathrm{Na}]=1.8 \pm 0.3)$ was in good agreement with the value reported by Lee et al. (2003) (1.9 \pm 0.3$)$ for pores formed by $\mathrm{Cry} 1 \mathrm{Ab}$ toxin in a planar lipid bilayer system. Conversely, conductances of the Cry1Ab-treated cell membrane for $\mathrm{Cl}^{-}$and $\mathrm{K}^{+}$were of similar magnitude. Our result is in line with the findings of Kirouac et al. (2003), working with Cry1Ab-treated brush border membrane vesicles in $150 \mathrm{~mm} \mathrm{KCl}$ solution, but is much lower than the value for $\mathrm{p}(\mathrm{K}) / \mathrm{p}(\mathrm{Cl})$ reported by either Lee et al. (2003) (7.0 \pm 2.6$)$ or Raussel et al. (2004) (3.5) from work on planar lipid bilayer systems. A possible explanation for this discrepancy is that both our preparation and that of Kirouac et al. (2003) contained endogenous chloride channels that may have been stimulated by the formation of a cationic pore, thus maintaining the potential despite the rise in overall conductance (Kirouac et al., 2003; Lorence et al., 1995; Peyronnet et al., 2000). It is tempting to speculate that this may be a part of a regulatory response enhancing the ability of the cell to survive exposure to Cry1Ab since an opening of chloride channels should hyperpolarize the cells and limit the efflux of potassium.

However, it should also be noted that both Lee et al. (2003) and Raussel et al. (2004) worked at considerably higher concentrations of external potassium (300 mmol/l) than those used in our experiments $(5 \mathrm{~mm})$ or those of Kirouac et al. (2003) (150 mm). It is also noteworthy that while Lee et al. (2003) worked at a $\mathrm{pH}$ of 8.5, in our experiments $\mathrm{pH}$ was buffered to 7.4. It has been suggested that at more acidic values of $\mathrm{pH}$ titration of negative moieties within the Cry toxin pore by protons occurs (Schwartz et al., 1991, 1993) and enhances the conductance for anions (Fortier et al., 2005; Tran et al., 2001). Similar effects of $\mathrm{pH}$ on selectivity have been reported for the large channels formed by botulinum, tetanus and diphtheria toxins (Hoch \& Finkelstein, 1985).

While solid evidence supports the notion that the presence of receptors is not a prerequisite of pore formation 
(Gazit et al., 1998; Masson et al., 1999; Schwartz et al., 1993, 1997a; Vie et al., 2001), the concentrations of $\mathrm{Cry} 1 \mathrm{Ab}$ toxin needed to observe effects used in our experiments $(100 \mathrm{ng} / \mathrm{ml})$ are lower than those used in most studies of pore formation in receptor-free artificial membranes (Peyronnet et al., 2001; Rausell et al., 2004; Schwartz et al., 1997a). A number of factors may have facilitated pore formation in our experiments.

One factor that needs to be discussed is the temperature. The detrimental effect of an elevation of temperature on lipid-lipid action in artificial lipid membranes is well known. Thus, membrane fluidity rises dramatically between $12^{\circ} \mathrm{C}$ and $37^{\circ} \mathrm{C}$, with a fourfold change in bending modulus of phosphocholine membranes (Niggemann, Kummrow \& Helfrich, 1995) and a 20-40\% reduction of the tension necessary for rupture (Shoemaker \& Vanderlick, 2003). Correspondingly, the rate at which Cry toxins can rupture lipid-lipid interactions and insert into the cell membrane rises with temperature (Guihard et al., 2000). An increase in temperature from $20^{\circ} \mathrm{C}$ to $37^{\circ} \mathrm{C}$ has been shown to increase the rate of pore formation in brush border membrane vesicles by a factor of five (Vachon et al., 2006). Interestingly, a temperature-induced increase in the toxicity of Bt toxins has also been observed in vivo (Katbeh-Bader, Khyami-Horani \& Mohsen, 1999). Since the vast majority of studies demonstrating toxin channel formation in receptor-free lipid bilayers were performed at room temperature, it should not come as a surprise that in these studies higher concentrations of Cry toxin were necessary to obtain significant results than in the present study.

A second factor that needs to be considered is the lipid composition of the membrane. Note that the stability of lipid bilayer preparations rises if the lipids used are neutral (Schwartz et al., 2001). For this reason, most studies of Cry toxin action on lipid bilayers have focused on such (unphysiological) preparations. The effects of lipid composition on the pore-forming action of Cry toxins have been documented many times both in the presence (Avisar et al., 2005; Zhuang et al., 2002) and in the absence (Butko et al., 1994; Fortier et al., 2005; Rausell et al., 2004; Vie et al., 2001; Yunovitz \& Yawetz, 1988) of receptors. Electrostatic interactions between the (hydrophilic) toxin and the (hydrophobic) membrane (Vachon et al., 2006) appear to be important for the insertion process, and thus, removal of the surface charge should have a detrimental effect on pore formation.

A further effect worth considering is membrane potential. Schwartz et al. (1997b) report the stimulating effect of a holding potential on insertion of toxin into artificial bilayers. In the present study, all cells were clamped to a holding potential of $-40 \mathrm{~m} V$ and exposed to a protocol of variable potentials that may have enhanced pore formation.
In light of the failure to detect cytotoxic effects of Cry $1 \mathrm{Ab}$ at a concentration of $100 \mathrm{ng} / \mathrm{ml}$ in a previous study (A. Bondzio, F. Stumpff, H. Martens, R. Einspanier, Validation of sheep rumen epithelial cells (REC) as a new in vitro model for evaluating the impact of recombinant food compounds, unpublished data), the effects reported here are unexpected. It should be noted that the facility of insertion can be greater in fragments of Cry1Ab than in the whole molecule. Thus, the N-terminal, hydrophobic $\alpha$-helix of Cry toxins (domain I) is lipophilic and inserts into artificial bilayer systems at very low concentrations (Gazit \& Shai, 1993; Grochulski et al., 1995; Puntheeranurak et al., 2004; Walters et al., 1993) when separated from the rest of the water-soluble toxin molecule. Ultimately, we cannot exclude the possibility that such fragments formed in our perfusion system, but this explanation seems farfetched. A more obvious difference between this patchclamp study and a previous study of cell vitality parameters (A. Bondzio, F. Stumpff, H. Martens, R. Einspanier, Validation of sheep rumen epithelial cells (REC) as a new in vitro model for evaluating the impact of recombinant food compounds, unpublished data) is that in this study only a minority of cells were included in which at least parts of the lipid cell membrane were exposed to allow seal formation with the glass pipette. It appears possible that the majority of ruminal epithelial cells in vitro and in vivo are covered by a coating that not only interferes with seal formation but also serves to efficiently protect the cells from the pore-forming activity of Cry1 $\mathrm{Ab}$ and its fragments. Thus, it has been suggested that certain membrane proteins in resistant target populations may serve as decoys preventing toxin action (Jurat-Fuentes, Gould \& Adang, 2003; Lee et al., 1995; Shitomi et al., 2006).

However, it should be noted that Cyt toxins, another group of toxins derived from $B$. thuringiensis, are toxic only to dipteran larvae in vivo, although the ability of the toxins to form pores in a large number of eukaryotic cells is undisputed (Knowles et al., 1989; Thomas \& Ellar, 1983). This may indicate that a number of mechanisms (such as the presence of a robust, basolateral $\mathrm{Na}^{+}, \mathrm{K}^{+}$-ATPase) protect the ruminal epithelial cell from the cytotoxic effects of pore-forming toxins produced by bacteria that thrive in the rumen and that may also contribute to cell viability in the presence of high concentrations of Cry1 Ab in culture.

In summary, our study suggests that spontaneous insertion of Cry1 Ab into lipid membranes of perfused ruminal epithelial cells is possible at concentrations that are very high when compared to those observed in vivo but relatively low when compared to those usually necessary for pore formation in receptor-free membranes. It appears highly unlikely that the effects reported in this study are related to the presence of specific receptors for Cry1Ab in sheep ruminal epithelial cells. Instead, we suggest that a number of 
other factors that include the temperature $\left(37^{\circ} \mathrm{C}\right)$ and the lipid composition of the membrane (mammalian) may have contributed to the spontaneous formation of pores by Cry toxins (Masson et al., 2002; Slatin et al., 1990). Since the same concentration of Cry1 Ab did not affect the vitality of ruminal epithelial cells in vitro (A. Bondzio, F. Stumpff, $\mathrm{H}$. Martens, R. Einspanier, Validation of sheep rumen epithelial cells (REC) as a new in vitro model for evaluating the impact of recombinant food compounds, unpublished data), we suggest that ruminal cells are equipped with powerful mechanisms to resist the toxic effects not just of Cry $1 \mathrm{Ab}$ (Wiedemann et al., 2006) but also of other ionophores administered as antibiotics (Russell \& Houlihan, 2003) or produced by ruminal bacteria (Parker \& Feil, 2005). It thus appears highly unlikely that Cry toxin concentrations normally found in rumen contents after feeding $\mathrm{Bt}$ transgene plants will specifically interact with or influence the vitality of rumen epithelial cells in vivo.

Acknowledgements We thank Gabriele Kiselowski for expert assistance in preparing the cells. Cry1 Ab toxin was kindly provided by Dr. J. Jehle, Laboratory for Biotechnological Crop Protection, Palatinate, Germany (DLR Rhein-Pfalz, Germany) within BMBF project 01K0-31P2614. The financial support of the Margarete Marcus Charity is gratefully acknowledged.

\section{References}

Abdoun K, Stumpff F, Martens H (2006) Ammonia and urea transport across the rumen epithelium: a review. Anim Health Res Rev $7: 1-17$

Abdoun K, Stumpff F, Wolf K, Martens H (2005) Modulation of electroneutral $\mathrm{Na}$ transport in sheep rumen epithelium by luminal ammonia. Am J Physiol 289:G508-G520

Alcantara EP, Alzate O, Lee MK, Curtiss A, Dean DH (2001) Role of alpha-helix seven of Bacillus thuringiensis Cry1 Ab delta-endotoxin in membrane insertion, structural stability, and ion channel activity. Biochemistry 40:2540-2547

Avisar D, Segal M, Sneh B, Zilberstein A (2005) Cell-cycledependent resistance to Bacillus thuringiensis Cry1C toxin in Sf9 cells. J Cell Sci 118:3163-3171

Butko P, Cournoyer M, Pusztai-Carey M, Surewicz WK (1994) Membrane interactions and surface hydrophobicity of Bacillus thuringiensis delta-endotoxin CryIC. FEBS Lett 340:89-92

Chowdhury EH, Shimada N, Murata H, Mikami O, Sultana P, Miyazaki S, Yoshioka M, Yamanaka N, Hirai N, Nakajima Y (2003) Detection of Cry1 Ab protein in gastrointestinal contents but not visceral organs of genetically modified Bt11-fed calves. Vet Hum Toxicol 45:72-75

Folmer JD, Grant RJ, Milton CT, Beck J (2002) Utilization of Bt corn residues by grazing beef steers and Bt corn silage and grain by growing beef cattle and lactating dairy cows. J Anim Sci 80:1352-1361

Fortier M, Vachon V, Kirouac M, Schwartz JL, Laprade R (2005) Differential effects of ionic strength, divalent cations and $\mathrm{pH}$ on the pore-forming activity of Bacillus thuringiensis insecticidal toxins. J Membr Biol 208:77-87

Gazit E, Bach D, Kerr ID, Sansom MS, Chejanovsky N, Shai Y (1994) The alpha-5 segment of Bacillus thuringiensis delta- endotoxin: in vitro activity, ion channel formation and molecular modelling. Biochem J 304(pt 3):895-902

Gazit E, La Rocca P, Sansom MS, Shai Y (1998) The structure and organization within the membrane of the helices composing the pore-forming domain of Bacillus thuringiensis delta-endotoxin are consistent with an "umbrella-like" structure of the pore. Proc Natl Acad Sci USA 95:12289-12294

Gazit E, Shai Y (1993) Structural and functional characterization of the alpha 5 segment of Bacillus thuringiensis delta-endotoxin. Biochemistry 32:3429-3436

Graham C, Simmons NL (2005) Functional organization of the bovine rumen epithelium. Am J Physiol 288:R173-R181

Griffitts JS, Aroian RV (2005) Many roads to resistance: how invertebrates adapt to Bt toxins. Bioessays 27:614-624

Griffitts JS, Haslam SM, Yang T, Garczynski SF, Mulloy B, Morris H, Cremer PS, Dell A, Adang MJ, Aroian RV (2005) Glycolipids as receptors for Bacillus thuringiensis crystal toxin. Science 307:922-925

Grochulski P, Masson L, Borisova S, Pusztai-Carey M, Schwartz JL, Brousseau R, Cygler M (1995) Bacillus thuringiensis CryIA(a) insecticidal toxin: crystal structure and channel formation. J Mol Biol 254:447-464

Guihard G, Vachon V, Laprade R, Schwartz JL (2000) Kinetic properties of the channels formed by the Bacillus thuringiensis insecticidal crystal protein Cry1C in the plasma membrane of Sf9 cells. J Membr Biol 175:115-122

Hille B (2001) Ion Channels of Excitable Membranes. Sunderland, MA: Sinauer Associates

Hoch DH, Finkelstein A (1985) Gating of large toxin channels by $\mathrm{pH}$. Ann N Y Acad Sci 456:33-35

Jurat-Fuentes JL, Gould FL, Adang MJ (2003) Dual resistance to Bacillus thuringiensis Cry1 Ac and Cry2Aa toxins in Heliothis virescens suggests multiple mechanisms of resistance. Appl Environ Microbiol 69:5898-5906

Katbeh-Bader A, Khyami-Horani H, Mohsen ZH (1999) Effect of temperature on the susceptibility of Culiseta longiareolata (Macquart) (Dipt., Culicidae) to two standard strains of biocontrol bacteria. J Appl Entomol 123:629-631

Kirouac M, Vachon V, Rivest S, Schwartz JL, Laprade R (2003) Analysis of the properties of Bacillus thuringiensis insecticidal toxins using a potential-sensitive fluorescent probe. J Membr Biol 196:51-59

Knowles BH, Blatt MR, Tester M, Horsnell JM, Carroll J, Menestrina G, Ellar DJ (1989) A cytolytic delta-endotoxin from Bacillus thuringiensis var. israelensis forms cation-selective channels in planar lipid bilayers. FEBS Lett 244:259-262

Lee MK, Rajamohan F, Gould F, Dean DH (1995) Resistance to Bacillus thuringiensis CryIA delta-endotoxins in a laboratoryselected Heliothis virescens strain is related to receptor alteration. Appl Environ Microbiol 61:3836-3842

Lee MK, Walters FS, Hart H, Palekar N, Chen JS (2003) The mode of action of the Bacillus thuringiensis vegetative insecticidal protein Vip3A differs from that of Cry1Ab delta-endotoxin. Appl Environ Microbiol 69:4648-4657

Leonhard-Marek S, Stumpff F, Brinkmann I, Breves G, Martens H (2005) Basolateral $\mathrm{Mg}^{2+} / \mathrm{Na}^{+}$exchange regulates apical nonselective cation channel in sheep rumen epithelium via cytosolic $\mathrm{Mg}^{2+}$. Am J Physiol 288:G630-G645

Lorence A, Darszon A, Diaz C, Lievano A, Quintero R, Bravo A (1995) Delta-endotoxins induce cation channels in Spodoptera frugiperda brush border membranes in suspension and in planar lipid bilayers. FEBS Lett 360:217-222

Lutz B, Wiedemann S, Einspanier R, Mayer J, Albrecht C (2005) Degradation of Cry1 Ab protein from genetically modified maize in the bovine gastrointestinal tract. J Agric Food Chem 53:14531456 
Masson L, Tabashnik BE, Liu YB, Brousseau R, Schwartz JL (1999) Helix 4 of the Bacillus thuringiensis Cry1Aa toxin lines the lumen of the ion channel. J Biol Chem 274:31996-32000

Masson L, Tabashnik BE, Mazza A, Prefontaine G, Potvin L, Brousseau R, Schwartz JL (2002) Mutagenic analysis of a conserved region of domain III in the Cry1Ac toxin of Bacillus thuringiensis. Appl Environ Microbiol 68:194-200

Monette R, Savaria D, Masson L, Brousseau R (1994) Calciumactivated potassium channels in the UCR-SE-1a lepidopteran cell line from the beet armyworm (Spodoptera exigua). J Insect Physiol 40:273-282

Nguyen Thu H, Meise T, Langenbruch G-A, Jehle JA (2004) Production of Cry $1 \mathrm{Ab}$ toxin in E. coli for standardisation of insect bioassays. IOBC/WPRS Bull 27:125-130

Niggemann G, Kummrow M, Helfrich W (1995) The bending rigidity of phosphatidylcholine bilayers-dependences on experimentalmethod, sample cell sealing and temperature. J Physique II $5: 413-425$

Parker MW, Feil SC (2005) Pore-forming protein toxins: from structure to function. Prog Biophys Mol Biol 88:91-142

Peyronnet O, Vachon V, Schwartz JL, Laprade R (2000) Ion channel activity from the midgut brush-border membrane of gypsy moth (Lymantria dispar) larvae. J Exp Biol 203:1835-1844

Peyronnet O, Vachon V, Schwartz JL, Laprade R (2001) Ion channels induced in planar lipid bilayers by the Bacillus thuringiensis toxin Cry1Aa in the presence of gypsy moth (Lymantria dispar) brush border membrane. J Membr Biol 184:45-54

Puntheeranurak T, Uawithya P, Potvin L, Angsuthanasombat C, Schwartz JL (2004) Ion channels formed in planar lipid bilayers by the dipteran-specific Cry4B Bacillus thuringiensis toxin and its alpha1-alpha5 fragment. Mol Membr Biol 21:67-74

Rausell C, Munoz-Garay C, Miranda-CassoLuengo R, Gomez I, Rudino-Pinera E, Soberon M, Bravo A (2004) Tryptophan spectroscopy studies and black lipid bilayer analysis indicate that the oligomeric structure of Cry1Ab toxin from Bacillus thuringiensis is the membrane-insertion intermediate. Biochemistry 43:166-174

Russell JB, Houlihan AJ (2003) Ionophore resistance of ruminal bacteria and its potential impact on human health. FEMS Microbiol Rev 27:65-74

Schnepf E, Crickmore N, Van Rie J, Lereclus D, Baum J, Feitelson J, Zeigler DR, Dean DH (1998) Bacillus thuringiensis and its pesticidal crystal proteins. Microbiol Mol Biol Rev 62:775-806

Schwartz JL, Garneau L, Masson L, Brousseau R (1991) Early response of cultured lepidopteran cells to exposure to deltaendotoxin from Bacillus thuringiensis: involvement of calcium and anionic channels. Biochim Biophys Acta 1065:250-260

Schwartz JL, Garneau L, Savaria D, Masson L, Brousseau R, Rousseau E (1993) Lepidopteran-specific crystal toxins from Bacillus thuringiensis form cation- and anion-selective channels in planar lipid bilayers. J Membr Biol 132:53-62

Schwartz JL, Lu YJ, Sohnlein P, Brousseau R, Laprade R, Masson L, Adang MJ (1997a) Ion channels formed in planar lipid bilayers by Bacillus thuringiensis toxins in the presence of Manduca sexta midgut receptors. FEBS Lett 412:270-276

Schwartz JL, Potvin L, Chen XJ, Brousseau R, Laprade R, Dean DH (1997b) Single-site mutations in the conserved alternatingarginine region affect ionic channels formed by CryIAa, a Bacillus thuringiensis toxin. Appl Environ Microbiol 63:39783984

Schwartz JL, Potvin L, Coux F, Charles JF, Berry C, Humphreys MJ, Jones AF, Bernhart I, Dalla Serra M, Menestrina G (2001) Permeabilization of model lipid membranes by Bacillus sphaericus mosquitocidal binary toxin and its individual components. J Membr Biol 184:171-183
Schweigel M, Lang I, Martens $\mathrm{H}$ (1999) $\mathrm{Mg}^{2+}$ transport in sheep rumen epithelium: evidence for an electrodiffusive uptake mechanism. Am J Physiol 277:G976-G982

Shitomi Y, Hayakawa T, Hossain DM, Higuchi M, Miyamoto K, Nakanishi K, Sato R, Hori H (2006) A novel 96-kDa aminopeptidase localized on epithelial cell membranes of Bombyx mori midgut, which binds to Cry1Ac toxin of Bacillus thuringiensis. J Biochem (Tokyo) 139:223-233

Shoemaker SD, Vanderlick TK (2003) Material studies of lipid vesicles in the L(alpha) and L(alpha)-gel coexistence regimes. Biophys J 84:998-1009

Slatin SL, Abrams CK, English L (1990) Delta-endotoxins form cation-selective channels in planar lipid bilayers. Biochem Biophys Res Commun 169:765-772

Steggles JR, Wang J, Ellar DJ (2006) Discovery of Bacillus thuringiensis virulence genes using signature-tagged mutagenesis in an insect model of septicaemia. Curr Microbiol 53(4):303310

Stumpff F, Boxberger M, Krauss A, Rosenthal R, Meissner S, Choritz L, Wiederholt M, Thieme H (2005) Stimulation of cannabinoid (CB1) and prostanoid (EP2) receptors opens BKCa channels and relaxes ocular trabecular meshwork. Exp Eye Res 80:697-708

Thomas WE, Ellar DJ (1983) Bacillus thuringiensis var israelensis crystal delta-endotoxin: effects on insect and mammalian cells in vitro and in vivo. J Cell Sci 60:181-197

Tran LB, Vachon V, Schwartz JL, Laprade R (2001) Differential effects of $\mathrm{pH}$ on the pore-forming properties of Bacillus thuringiensis insecticidal crystal toxins. Appl Environ Microbiol 67:4488-4494

Vachon V, Schwartz JL, Laprade R (2006) Influence of the biophysical and biochemical environment on the kinetics of pore formation by Cry toxins. J Invertebr Pathol 92:160-165

Vie V, Van Mau N, Pomarede P, Dance C, Schwartz JL, Laprade R, Frutos R, Rang C, Masson L, Heitz F, Le Grimellec C (2001) Lipid-induced pore formation of the Bacillus thuringiensis Cry1Aa insecticidal toxin. J Membr Biol 180:195-203

Walters FS, Slatin SL, Kulesza CA, English LH (1993) Ion channel activity of N-terminal fragments from CryIA(c) delta-endotoxin. Biochem Biophys Res Commun 196:921-926

Wieczorek H, Gruber G, Harvey WR, Huss M, Merzendorfer H (1999) The plasma membrane $\mathrm{H}^{+}-\mathrm{V}$-ATPase from tobacco hornworm midgut. J Bioenerg Biomembr 31:67-74

Wiedemann S, Lutz B, Kurtz H, Schwarz FJ, Albrecht C (2006) In situ studies on the time-dependent degradation of recombinant corn DNA and protein in the bovine rumen. J Anim Sci 84:135-144

Wolfersberger MG (1990) The toxicity of two Bacillus thuringiensis delta-endotoxins to gypsy moth larvae is inversely related to the affinity of binding sites on midgut brush border membranes for the toxins. Experientia 46:475-477

Wolfersberger MG (1992) V-ATPase-energized epithelia and biological insect control. J Exp Biol 172:377-386

Wolfersberger MG (1995) Permeability of Cry I toxin channels. In: Clark JM (ed), Molecular Action of Insecticides on Ion Channels. Washington, DC: American Chemical Society

Yunovitz H, Yawetz A (1988) Interaction between the deltaendotoxin produced by Bacillus thuringiensis ssp. entomocidus and liposomes. FEBS Lett 230:105-108

Zhang X, Candas M, Griko NB, Taussig R, Bulla LA Jr (2006) A mechanism of cell death involving an adenylyl cyclase/PKA signaling pathway is induced by the Cry1 Ab toxin of Bacillus thuringiensis. Proc Natl Acad Sci USA 103:9897-9902

Zhuang M, Oltean DI, Gomez I, Pullikuth AK, Soberon M, Bravo A, Gill SS (2002) Heliothis virescens and Manduca sexta lipid rafts are involved in Cry1A toxin binding to the midgut epithelium and subsequent pore formation. J Biol Chem 277:13863-13872 